\title{
Okul Öncesi Öğretmenlerinin Hazırladıkları Etkinlik Planlarında Sosyal ve Duygusal Gelişim Alanına Yer Verme Düzeyi
}

\author{
The Level of Including Zones of Social and Emotional Development in the \\ Activity Plans of Pre-School Teachers
}

\begin{abstract}
Emine KIZILTAŞ * Eren ERTÖR ${ }^{* *}$ Abdülhamit KARADEMIR ${ }^{* * *}$

Öz: Bu çalışmada okul öncesi öğretmenlerinin okul öncesi eğitim kurumlarında hazırladıkları planlarda hangi sosyal ve duygusal becerilere ne sıklıkla yer verdiğinin belirlenmesi amaçlanmıştır. Araştırmada belirlenen amaç doğrultusunda nitel araştırma desenlerinden durum çalışması kullanılmıştır. Araştırmanın verilerini Ağrı ili merkez ilçedeki bağımsız anaokullarında çalışan 38 okul öncesi öğretmeninin 2014-2015 eğitim-öğretim yılı bahar döneminde hazırlayarak uyguladıkları etkinlik planlarından doküman inceleme yöntemi ile edinilen veriler oluşturmaktadır. Elde edilen veriler içerik analizi kullanılarak çözümlenmiş ve elde edilen sonuçlar frekanslar halinde tablolarla verilmiştir. Araştırma sonucunda okul öncesi öğretmenlerinin etkinlik planlarında çocuklar için en çok "kendisini yaratıcı yollarla ifade eder, kendisine ait özellikleri tanıtır, değişik ortamlardaki kurallara uyar ve bir olay ya da durumla ilgili olarak başkalarının duygularını açıklar" kazanımlarına yer verdikleri, en az ise "sanat eserlerinin değerini fark eder, başkalarıyla sorunlarını çözer, ailesiyle ilgili özellikleri tanıtır” kazanımlarına yer verdikleri görülmüştür. Etkinlik planlarında sosyal ve duygusal gelişimle ilgili olarak en çok "duygu düşünce ve hayallerini özgün yollarla ifade eder, adını ve/veya soyadını söyler" göstergelerine yer verildiği görülmüştür. Öğretmenlerin sosyal ve duygusal gelişimle ilgili en az yer verdikleri göstergeler ise "evin adresini söyler, telefon numarasını söyler, gerekli zamanlarda uzlaşmacı davranır, sanat eserleri ile ilgili duygularını açıklar ve başkalarının haklarını korumak için ne yapması gerektiğini söyler" göstergeleridir.
\end{abstract}

Anahtar sözcükler: Okul Öncesi Eğitim, Sosyal ve Duygusal Gelişim, Etkinli Planı, Kazanım

Abstract: The object of this study was to determine how often and which social and emotional skills are included in the plans prepared by preschool teachers in preschool education institutions. A case study among qualitative research designs was used in the direction to the purpose determined in this research. Data for this study was obtained through using the document analysis method regarding the activity plans prepared and applied by 38 pre-school teachers working in independent kindergartens in the central district of Ağr1 Province. The data includes activity plans for the spring term of the 2014-2015 academic year. The data obtained was analyzed using content analysis and the results are given with frequencies in tables. As a result of this research, it was found that the pre-school teachers include achievements such as $s / h e$ expresses himself/herself with creative ways, s/he introduces his/her characteristics, s/he obeys the rules in different environments and s/he explains the emotions of others related to an event or situation the most for the children in the activity plans, and s/he realizes the value of artworks, s/he solves his/her problems with others, s/he introduces the characteristics of his/her family the least. It was found that preschool teachers include achievements such as s/he expresses his/her emotions, thoughts and dreams in unique ways, s/he can tell his/her name and/or surname related to social and emotional development the most; and s/he can tell his/her home address, s/he can tell his/her phone number, s/he becomes agreeable when necessary, s/he expresses his/her feelings related to artworks and s/he can tell what to do to defend the rights of others.

Keywords: Preschool, Social and Emotional Development, Activity Planning, Achievement

* $\quad$ Dr. Öğr. Ü., Ağrı İbrahim Çeçen Üni., SHMYO Çocuk Bakımı ve Gençlik Hizm. Blm., Ağrı. ekiziltas@agri.edu.tr

** Öğr. Gör., Ağrı İbrahim Çeçen Üni., SHMYO Çocuk Bakımı ve Gençlik Hizm. Blm., Ağrı. eertor@ @agri.edu.tr

**** Dr. Öğr. Ü., Muş Alparslan Üni., Eğitim Fak., Okul Öncesi Eğitimi ABD., Muş. a.karademir@alparslan.edu.tr 
Okul öncesi eğitim dönemi eğitimcilerine göre; çocukların ihtiyaçları ve becerilerine uygun öğrenme ortamları oluşturulmalı ve çocuklar desteklemelidirler. Öğrenmenin çok erken yaşlarda başladığı düşünüldüğünde, iyi bir bakım ve eğitim birbirinin tamamlayası durumundadır. Dikkatli bir planlamayla, çocukların deneyimleri geliştirmeli, uygun müdahalelerle çocuklara firsatlar sunulmalıdır. Ancak bu noktada çocukların bireysel farklılıkları göz ardı edilmeden bireysel öğrenme hızları kişisel olarak dikkate alınarak gelişimsel özelliklere yönelik içerikler oluşturulmalıdır. Bireysel özelliklerin yanı sıra kültürel ve fiziksel çeşitliliğe de saygı duyularak önyargılardan uzak bir tutum sergilenmelidir. Eğitimciler çocuklarını yakından tanımalı ve gerekli durumlarda ailelerle yakın ilişkiler kurarak ilk elden çocuk hakkında bildi edinmeye çalışmalıdır. Bununla birlikte çocukların her anına eşlik edebilecek yöntemleri kullanarak onlarla birlikte teşvik edici ve cesaretlendirici etkinliklerde bir arada oyunlaştırılmış deneyimler yaşamalıdırlar. Araştırmalar, çocukların temel becerileri edinmelerinde geniş çerçeveli deneyimlerin önemli olduğunu göstermiştir (Elkinson \& Elkinson 2000; Gregoriadis \& Grammatikopoulos 2013). Çocukların öğrenmelerinde içerik, dikkatli bir şekilde planlanmalı, çocuklara sunulan tecrübeler ve süreç içindeki rolleri önemsenmelidir. Çünkü çocukların geçmiş yaşantıları, değerleri ve inançları onların öğrenmesini etkilemektedir (Curtis 2002).

Yapılan çalışmalarda okul öncesi eğitim programlarında bulunması gereken unsurlar ise şöyle belirtilmiştir. Drummond'a göre (1993) öğretmenlerin hazırlaması gereken eğitim programları, bir çocuğun yaş ve gelişimine uygun kavramlar, bilgi, tutum ve becerileri, Ball'a göre ise (1994), çocukların öğrenmesi gereken tüm etkinlikleri ve deneyimleri (planlı ve planlanmamış, formal ve informal, açık ve gizli) içermelidir. Curtis'e göre ise (2002) en geniş anlamda programın öğrenme sürecinin; bir çocuğun nasıl öğrendiği, ne zaman öğrendiği, nerede ve niçin öğrendiğini de kapsayacak şekilde organize edilmesi gerektiğini belirtmiştir. Program, çocukların herhangi bir yetişkin müdahalesi olmadan oyunlarını özgürce oynamaları için firsatlar sunmalıdır. Kimsenin sorumlu olmadığı bu durumlarda çocuklar işbirliği yapmayı, izin almayı, kendini savunmayı, kendi kendini değerlendirmeyi ve grupla etkileşim dinamiklerinden hoşnut olmayı öğrenmektedir (Rivers et al. 2013). Çocuklar okul öncesi eğitim kurumlarında aile dışındaki yetişkinlerle etkili bir etkileşim kurabilmekte daha da önemlisi akran gruplarıyla sosyalleşmekte, dünya hakkında daha fazla tartışma ve öğrenme olanağı bulabilecek biçimde öğrenme ortamı düzenlenmelidir (Rivers et al. 2013). Aynı zamanda program hazırlanırken aile katılım çalışmalarına da yer verilmelidir. Burada unutulmaması gereken şey çocuğun aile içinde kabul edilebilir davranışlarının ve edindiği sosyal becerilerin farklı ortamlarda kabul edilenden çok farklı olabildiğidir (Rivers et al. 2013). Bu nedenlerden dolayı çocuğa model olarak kurum ve aile ortamında ortak amaçların ve yaklaşımların benimsenerek sergilenmesi gereklidir (OBADER 2013).

Sosyal ve duygusal becerilerin geliştirilmesi, erken öğrenme ve gelişimin önemli bir bileşenidir ve okul öncesi eğitim programları gelişmekte olan çocuğun ihtiyaçlarını karşılamak için geleneksel bilişsel becerilerden daha fazla sosyal ve duygusal becerilere odaklanmalıdır (Zigler \& Bishop-Josef 2006). Aslında okul öncesi öğretmenleri çocukların sosyal ve duygusal becerilerine diğer becerilerinden daha fazla önem vermektedirler (Boyd et al. 2005). Ancak birçok çocuk yeterli sosyal ve duygusal beceriye sahip olmadan okul öncesi eğitim kurumlarına gelmekte (Blair 2002; Eisenberg et al. 2004; McClelland et al. 2007) ve özellikle düşük gelirli ailelerin çocukları bu becerilerden daha yoksun olarak eğitime başlamaktadır (Howse et al. 2003).

Çocuklara erken yaşlardan itibaren okul öncesi eğitim kurumlarında; kendisini ve çevresini tanıması gerektiği, kendisine verilen görevi ve sorumluluğun üstesinden gelmek için birçok yol deneyebileceği bundan dolayı asla pes etmeden kendine olan güveni hiç kaybetmemesi gerektiği 
öğretilmeye çalışılır. MEB Okulöncesi Eğitim Programına bakıldığında çocukların sosyal duygusal anlamda bu kazanımların yanında; sosyal uyum, çevreyle işbirliği ve yardımlaşma, başkalarının duygularını anlama ve kendi duygularını en etkili yolla ifade etme, kültürel farklılıklara ve düşüncelere saygı vb. kazanımların yer alması (MEB 2013) çocukları gelecek yaşama hazırlama konusunda eğitimcilerin sosyal ve duygusal gelişim alanında sorumluluklarının ağır olduğunu açıkça göstermektedir. Bununla birlikte çocukların erken dönemde kazandıkları sosyal deneyimler onların sonraki yaşamlarının önemli bir yordayıcı olacaktır. örneğin akranları tarafından reddedilen çocuklar büyük bir olasılıkla ergenlikte ve yetişkinlikte suça yönelik davranışlara karışmakta (Kupersmidt \& Coie 1990), okuldan atılmakta, 18 yaşın altında işsiz kalabilmekte (Fergusson et al. 2000) ve şiddete maruz kalabilmektedirler (Tremblay et al. 1992). Bu yüzden okul öncesi öğretmenlerinin küçük çocuklar için hazırladıkları etkinliklerin niteliklerinin ve bu etkinliklerde sosyal ve duygusal becerilere ne derecede yer verdiklerinin önemli olduğu düşünülmektedir.

Araştırmalar okul öncesi öğretmenlerinin, çocukların küçük yaşlardan itibaren her gelişim alanlarında olduğu gibi sosyal ve duygusal gelişiminin desteklenmesinde de önemli bir rol oynadığını ortaya koymuştur (Wang et al. 2008; Han 2012; Hollingsworth \& Winter 2013). Fakat okul öncesi öğretmenlerinin erken çocukluk programı uygulamaları, nitelik ve çerçeve bakımından büyük ölçüde farklılık göstermektedir. Ayrıca uygulanan programların hiçbiri çocukların akademik, duygusal ve sosyal ihtiyaçlarını etkili bir şekilde karşılamamaktadır (Pianta et al. 2009). Bunun yanı sıra çocukların olumlu davranışlar edinmelerine katkı sağlamak için programın hangi öğelerinin okul öncesi eğitim programlarına dahil edilmesi gerektiği konusunda da tartışmalar devam etmektedir (Rivers et al. 2013). Bazı araştırmalar okul öncesi eğitim döneminde kazanılan akademik becerilerin (matematiksel kavramlar gibi) sonraki akademik başarıların güçlü bir yordayıcısı olduğunu desteklerken (Duncan et al. 2007), bazı araştırmalar ise çocukların akademik bir programa başlamadan önce sosyal ve duygusal becerilerinin uygulamalı olarak geliştirilmesi gerektiğini savunmaktadır (McClelland et al. 2000).

Alan yazın incelendiğinde okul öncesi dönemde çocukların sosyal becerileri erken yaşlarda edinmelerinin ne kadar önemli olduğunu gösteren uluslararası (Ladd 1990; Ladd et al. 1996; Masten \& Coatsworth 1998; Elkinson \& Elkinson 2000; Rubin et al. 2006; Lillvist et al. 2009; Whitted 2011; Serpell \& Mashburn 2012; Bikos \& Gregoriadis 2012; Gregoriadis \& Grammatikopoulos 2013; Santrock 2014) ve ulusal (Kuru-Turaşl1 2006; Seven 2006; Eraslan-Çapan 2006; Dereli 2008; Gülay 2008; Özbey 2009; Ceylan 2009; Günindi 2010; Ayyıldız 2011; Özdemir-Topaloğlu 2013; Pekdoğan 2016) pek çok araştırma bulunmaktadır. Fakat okul öncesi öğretmenlerinin çocuklar için hazırladıkları eğitim planlarında sosyal ve duygusal becerilere ne derece yer verdiğini gösteren bir çalışma yapılmadığı görülmektedir. Bu çalışmada öğretmenlerin okul öncesi eğitim kurumlarında hazırladıkları eğitim planlarında hangi sosyal ve duygusal becerilere ne sıklıkla yer verdiğinin belirlenmesi amaçlanmıştır. Çalışmanın bu eksikliği gidererek alana katk1 sağlayacağı düşünülmektedir.

\section{Araştırma problemi}

Okul öncesi öğretmenlerinin hazırladıkları etkinlik planlarında sosyal ve duygusal gelişim alanına yer verme düzeyi nedir?

\section{Alt Problemler:}

1. Okul öncesi öğretmenlerinin hazırladıkları etkinlik planlarında sosyal ve duygusal gelişim ile ilgili kazanımlara yer verme düzeyi nedir?

2. Okul öncesi öğretmenlerinin hazırladıkları etkinlik planlarında sosyal ve duygusal 
gelişim ile ilgili göstergelere yer verme düzeyi nedir?

3. Okul öncesi ögretmenlerinin hazırladıkları etkinlik planlarında sosyal ve duygusal gelişim ile ilgili etkinliklere yer verme düzeyi nedir?

4. Okul öncesi öğretmenlerinin hazırladıkları etkinlik planlarında sosyal ve duygusal gelişim ile ilgili etkinlik biçimlerine yer verme düzeyi nedir?

\section{Yöntem}

Araştırmada nitel araştırma yöntemlerinden durum incelemesi kullanılmıştır (Cohen \& Manion 1992; Yıldırım \& Şimşek 2006). Durum incelemesi araştırmada hedeflenen olgu ve olaylar hakkında bilgi içeren yazılı materyallerin analizini kapsamaktadır (Yıldırım \& Şimşek 2006). Burada ki asıl amaç ise incelenen durumu etraflıca tanımlamak ve açıklamaktır. Bu nedenle bu araştırmada doküman incelemesi yoluyla veri toplanmıştır.

\section{Veri Kaynağı ve Verilerin Toplanması}

Araştırmanın veri kaynağını Ağrı ili merkez ilçedeki bağımsız anaokullarında çalışan 38 okul öncesi öğretmeninin 2014-2015 bahar döneminde hazırladıkları etkinlik planı oluşturmaktadır. Öğretmenler planlarını 2013 yılında MEB tarafından uygulamaya konulan program kitabını temel alarak oluşturmuşlardır. Çalışmada okul öncesi öğretmenlerinin 2014-2015 eğitimöğretim yılı bahar döneminde hazırlayarak uyguladıkları etkinlik planları incelenmiştir. Etkinlik planları etkinlik türlerine göre kategorize edilerek kullanılan kazanım ve göstergeleri ham veri olarak toplamışlardır.

\section{Verilerin Analizi}

Araştırmada toplanan verilerin analizinde içerik analizinden faydalanılmıştır. Araştırmada sosyal ve duygusal becerilerin, etkinlik planlarında tekrar etme dereceleri, kazanım ve göstergeler, etkinlik türleri olarak kodlanmış ve frekans dağılımları çıkarılmıştır. Araştırmada verilerin güvenirliği için araştırmacılar ve okul öncesi eğitim alanında uzman iki kişi tarafından yapılan kodlamalar üzerinde Miles ve Huberman tarafindan geliştirilen, Güvenirlik= Görüş Birliği/ Görüş Birliği + Görüş Ayrılığ X 100 formülü uygulanmıştır. Bu formüle göre kodlamalar arasındaki uyuşum yüzdesi \%86.05 olarak hesaplanmıştır (Miles \& Huberman 1994 akt. Yüksel 2011, 182).

\section{Bulgular}

Tablo 1'de okul öncesi öğretmenlerinin hazırladıkları etkinlik planlarında sosyal ve duygusal gelişim ile ilgili kazanımlara yer verme düzeyi sunulmuştur.

Tablo 1. Okul Öncesi Öğretmenlerinin Hazırladıkları Etkinlik Planlarında Sosyal ve Duygusal Gelişim ile İlgili Kazanımlara Yer Verme Düzeyi

\begin{tabular}{ll}
\hline Kazanımlar & F \\
\hline 1. "Kendisine ait özellikleri tanıtır" & 455 \\
2. "Ailesiyle ilgili özellikleri tanıtır" & 81 \\
3. "Kendini yaratıcı yollarla ifade eder" & 594 \\
4. "Bir olay ya da durumla ilgili olarak başkalarının duygularını açıklar" & 418 \\
5. "Bir olay ya da durumla ilgili olumlu/ olumsuz duygularını uygun yollarla gösterir" & 199 \\
6. "Kendisinin ve başkalarının haklarını korur" & 133 \\
7. "Bir işi ya da görev başarmak için kendini güdüler" & 207 \\
8. "Farklılıklara saygı gösterir" & 157 \\
9. "Farklı kültürel özellikleri açıllar" & 137 \\
\hline
\end{tabular}


10."Sorumluluklarını yerine getirir"

11."Atatürk ile ilgili etkinliklerde sorumluluk alır" 156

12."Değişik ortamlardaki kurallara uyar”" 444

13."Estetik değerleri korur” 106

14."Sanat eserlerinin değerini fark eder" $\quad 31$

15."Kendine güvenir" $\quad 313$

16. “Toplumsal yaşamda bireylerin farklı rol ve görevleri olduğunu açıklar” 174

17."Başkalarıyla sorunlarını çözer”

Tablo 1'e göre okul öncesi öğretmenlerinin hazırladıkları etkinlik planlarında sosyal ve duygusal gelişim ile ilgili en çok yer verdikleri kazanımların "kendisini yaratıcı yollarla ifade eder, kendisine ait özellikleri tanıtır, değişik ortamlardaki kurallara uyar ve bir olay ya da durumla ilgili olarak başkalarının duygularını açıklar" olduğu görülmektedir. En az yer verdikleri kazanımların ise "sanat eserlerinin değerini fark eder, başkalarıla sorunlarını çözer ve ailesiyle ilgili özellikleri tanıtır" olduğu görülmektedir. Tablo 1'e göre okul öncesi öğretmenlerinin hazırladıkları etkinlik planlarında sosyal ve duygusal gelişimle ilgili kazanımlara dengeli bir şekilde yer vermedikleri görülmektedir. Öğretmenlerin bazı kazanımlara sıklıkla yer verirken bazılarına çok az yer verdikleri tespit edilmiştir.

Tablo 2'de okul öncesi öğretmenlerinin hazırladıkları etkinlik planlarında sosyal ve duygusal gelişim ile ilgili göstergelere yer verme düzeyi sunulmuştur.

Tablo 2. Okul Öncesi Öğretmenlerinin Hazırladıkları Etkinlik Planlarında Sosyal ve Duygusal Gelişim ile İlgili Göstergelere Yer Verme Düzeyi

\begin{tabular}{|c|c|}
\hline Göstergeler (G) & f \\
\hline Kazanım 1. G 1. "Adını ve /veya soyadını söyler" & 187 \\
\hline Kazanım 1. G 2. "Yaşını söyler" & 121 \\
\hline Kazanım 1. G 3. "Fiziksel özelliklerini söyler" & 75 \\
\hline Kazanım 1. G 4. "Duyuşsal özelliklerini söyler” & 72 \\
\hline Kazanım 2. G 1. "Anne/babasının adını, soyadını mesleğini vb. söyler" & 40 \\
\hline Kazanım 2. G 2. "Anne/babasının saç rengi, boyu, göz rengi gibi özelliklerini söyler" & 23 \\
\hline Kazanım 2. G 3. "Teyze/amca gibi yakın akrabalarının isimlerini söyler" & 11 \\
\hline Kazanım 2. G 4. "Telefon numarasını söyler" & 5 \\
\hline Kazanım 2. G 5. "Evin adresini söyler" & 2 \\
\hline Kazanım 3. G 1. "Duygu, düşünce ve hayallerini özgün yollarla ifade eder" & 287 \\
\hline Kazanım 3. G 2. "Nesneleri alışılmışın dışında kullanır" & 153 \\
\hline Kazanım 3. G 3. "Özgün özellikler taşıyan ürünler oluşturur” & 154 \\
\hline Kazanım 4. G 1. "Başkalarının duygularını söyler" & 146 \\
\hline Kazanım 4. G 2. "Başkalarının duygularının nedenlerini söyler" & 146 \\
\hline Kazanım 4. G 3. "Başkalarının duygularının sonuçlarını söyler" & 126 \\
\hline Kazanım 5. G 1. "Olumlu/ olumsuz duygularını olumlu sözel ifadeler kullanarak açıklar” & 124 \\
\hline Kazanım 5. G 2. "Olumsuz duygularını olumlu davranışlarla gösterir" & 75 \\
\hline Kazanım 6. G 1. "Haklarını söyler" & 47 \\
\hline Kazanım 6. G 2. "Başkalarının hakları olduğunu söyler" & 56 \\
\hline Kazanım 6. G 3. "Haksızlığa uğradığında neler yapabileceğini söyler" & 10 \\
\hline Kazanım 6. G 4. "Başkalarının haklarını korumak için ne yapması gerektiğini söyler" & 20 \\
\hline Kazanım 7.G 1. "Yetişkin yönlendirmesi olmadan bir işe başlar" & 122 \\
\hline Kazanım 7.G 2. "Başladığı iş zamanında bitirmek için çaba gösterir" & 88 \\
\hline Kazanım 8.G 1. "Kendisinin farklı özellikleri olduğunu söyler" & 70 \\
\hline
\end{tabular}




\begin{tabular}{|c|c|}
\hline Göstergeler (G) & $\mathbf{f}$ \\
\hline Kazanım 8. G 2. “İnsanların farklı özellikleri olduğunu söyler” & 60 \\
\hline Kazanım 8. G 3. "Etkinliklerde farklı özellikteki çocuklarla birlikte yer alır & 27 \\
\hline Kazanım 9. G 1. "Kendi ülkesinin kültürüne ait özellikleri söyler" & 60 \\
\hline Kazanım 9. G 2. "Kendi ülkesinin kültüre ile diğer kültürlerin benzer ve farklı özelliklerini söyler” & 37 \\
\hline Kazanım 9. G 3. "Farklı ülkelerin kendine özgü kültürel özellikleri olduğunu söyler” & 40 \\
\hline Kazanım 10. G 1. "Sorumluluk almaya istekli olduğunu gösterir" & 154 \\
\hline Kazanım 10. G 2. "Üstlendiği sorumluluğu yerine getirir" & 133 \\
\hline Kazanım 10. G 3. "Sorumluluklar yerine getirilmediğinde olası sonuçları söyler" & 92 \\
\hline Kazanım 13. G 3. "Çevredeki güzelliklere değer verir" & 42 \\
\hline Kazanım 14. G 1. "Sanat eserlerinde gördüklerini ve işittiklerini söyler" & 8 \\
\hline Kazanım 14. G 2. "Sanat eserleri ile ilgili duygularını açıklar" & 7 \\
\hline Kazanım 14. G 3. "Sanat eserlerinin korunmasına özen gösterir" & 16 \\
\hline Kazanım 15. G 1. "Kendine ait beğendiği ve beğenmediği özelliklerini söyler" & 68 \\
\hline Kazanım 15. G 2. "Grup önünde kendini ifade eder" & 121 \\
\hline Kazanım 15. G 3. "Gerektiği durumlarda farklı görüşlerini söyler" & 90 \\
\hline Kazanım 15. G 4. "Gerektiğinde liderliği üstlenir" & 34 \\
\hline Kazanım 16. G 1. "Toplumda farklı rol ve görevlere sahip kişiler olduğunu söyler” & 89 \\
\hline Kazanım 16. G 2. "Aynı kişinin farklı rol ve görevleri olduğunu söyler” & 85 \\
\hline Kazanım 17. G 1. "Başkaları ile sorunlarını onlarla konuşarak çözer" & 11 \\
\hline Kazanım 17. G 2. "Arkadaşlarıyla sorunlarını çözemediği zamanlarda yetişkinlerden yardım ister" & 30 \\
\hline Kazanım 17. G 3. "Gerekli zamanlarda uzlaşmacı davranır" & 5 \\
\hline
\end{tabular}

Tablo 2 incelendiğinde okul öncesi öğretmenlerinin hazırladıkları etkinlik planlarında sosyal ve duygusal gelişimle ilgili en çok kazanım 3'te gösterge 1'de "duygu düşünce ve hayallerini özgün yollarla ifade eder" kazanım 1'de gösterge 1 "adını ve/veya soyadını söyler" kazanım 10 'da gösterge 1 "sorumluluk almaya istekli olduğunu gösterir" ve kazanım 3'te gösterge 3 “özgün özellikler taşlyan ürünler oluşturur" yer verdikleri görülmektedir. Ayrıca öğretmenlerin sosyal ve duygusal gelişimle ilgili en az yer verdikleri göstergelerin kazanım 2'de gösterge 5 evin adresini söyler, gösterge 4 telefon numarasını söyler, kazanım 17'de gösterge 3 gerekli zamanlarda uzlaşmacı davranır, kazanım 14'te gösterge 2 "sanat eserleri ile ilgili duygularını açıklar" gösterge 1 "sanat eserlerinde gördüklerini ve işittiklerini söyler" ve kazanım 6' da gösterge 4 "başkalarının haklarını korumak için ne yapması gerektiğini söyler" olduğu görülmektedir.

Tablo 2'ye göre öğretmenlerin hazırladıkları etkinlik planlarında sosyal ve duygusal gelişim ile ilgili göstergelere dengeli bir biçimde yer vermedikleri görülmektedir. Öğretmenlerin bazı göstergelere sıklıkla yer verdiği görülürken, bazılarına yer verme düzeylerinin oldukça düşük olduğu görülmektedir. Tablo 3'te okul öncesi öğretmenlerinin hazırladıkları etkinlik planlarında sosyal ve duygusal gelişim ile ilgili etkinliklere yer verme düzeyi sunulmuştur.

Tablo 3. Okul Öncesi Öğretmenlerinin Hazırladıkları Etkinlik Planlarında Sosyal ve Duygusal Gelişim ile İlgili Etkinliklere Yer Verme Düzeyi

\begin{tabular}{ll}
\hline Etkinlik Çeşidi & f \\
\hline Sanat Etkinliği & 830 \\
Türķe Etkinliği & 1079 \\
Drama Etkinliği & 486 \\
Fen Etkinliği & 499 \\
Matematik Etkinliği & 62 \\
Alan Gezisi Etkinliği & 61 \\
\hline
\end{tabular}




\begin{tabular}{ll}
\hline Hareket Etkinliği & 80 \\
Müzik Etkinliği & 535 \\
Okuma Yazmaya Hazırlık Etkinliği & 516 \\
Oyun Etkinliği & 749 \\
\hline
\end{tabular}

Tablo 3 incelendiğinde, okul öncesi öğretmenlerinin hazırladıkları etkinlik planlarında sosyal ve duygusal gelişim ile ilgili etkinliklere en çok Türkçe, sanat, oyun, müzik, okuma yazmaya hazırlık, fen ve drama etkinliğinde yer verdiği görülmektedir. Öğretmenlerin sosyal ve duygusal gelişim ile ilgili etkinliklere en az ise; alan gezisi, hareket etkinliği ve matematik etkinliğinde yer verdikleri görülmektedir.

Tablo 4'te okul öncesi öğretmenlerinin hazırladıkları etkinlik planlarında sosyal ve duygusal gelişim ile ilgili etkinlik biçimlerine yer verme düzeyi sunulmuştur.

Tablo 4. Okul Öncesi Öğretmenlerinin Hazırladıkları Etkinlik Planlarında Sosyal ve Duygusal Gelişim ile İlgili Etkinlik Biçimlerine Yer Verme Düzeyi

\begin{tabular}{ll}
\hline Etkinlik Biçimi (Şekli) & F \\
\hline Bireysel Etkinlikler & 1101 \\
Bütünleştirilmiş (Büyük-Küçük) Grup Etkinliği & 1529 \\
Büyük Grup Etkinliği & 410 \\
Küçük Grup Etkinliği & 410 \\
\hline
\end{tabular}

Tablo 4 incelendiğinde; okul öncesi öğretmenlerinin hazırladıkları etkinlik planlarında sosyal ve duygusal gelişim ile ilgili uygulanan etkinliklerin biçimleri incelendiğinde en çok bütünleştirilmiş (büyük-küçük) grup etkinliklerine yer verdikleri, en az ise bağımsız büyük ve küçük grup etkinliklerine yer verdikleri görülmektedir.

\section{Tartışma Sonuç ve Öneriler}

Araştırma sonucunda okul öncesi öğretmenlerinin hazırladıkları etkinlik planlarında sosyal ve duygusal gelişim alanı ile ilgili kazanım ve göstergelere oldukça farklı düzeylerde yer verdikleri görülmüştür. Etkinlik planlarında en çok kendisini yaratıcı yollarla ifade eder, kendisine ait özellikleri tanıtır, değişik ortamlardaki kurallara uyar ve bir olay ya da durumla ilgili olarak başkalarının duygularını açıklar, kazanımlarına yer verdikleri görülmektedir. En az yer verdikleri kazanımlar ise sanat eserlerinin değerini fark eder, başkalarıyla sorunlarını çözer, ailesiyle ilgili özellikleri tanıtır, kazanımlarıdır. Araştırmalarda okul öncesi öğretmenlerinin sınıfta sosyal ve duygusal beceriler konusunda yaptıkları etkinliklerin son derece değerli olduğu vurgulanmasına rağmen (Rimm-Kaufman et al. 2000), eğitimcilerin bu tür becerilerin geliştirilmesini desteklemek için belirli uygulama, yöntem ve stratejilerden genellikle yoksun oldukları belirtilmektedir (Hemmeter et al. 2008). Araştırma sonuçları, çalışmada okul öncesi öğretmenlerinin etkinliklerinde sosyal ve duygusal gelişimle ilgili diğer kazanımlara neden daha az yer verdiklerinin bir açıklayıcısı ve yordayıcısı olabilir.

Okul öncesi öğretmenlerinin hazırladıkları etkinlik planlarında sosyal ve duygusal gelişimle ilgili en çok duygu düşünce ve hayallerini özgün yollarla ifade eder, adını ve/veya soyadını söyler, sorumluluk almaya istekli olduğunu gösterir, özgün özellikler taşıyan ürünler oluşturur göstergelerine yer verdikleri görülmüştür. Öğretmenlerin sosyal ve duygusal gelişimle ilgili en az yer verdikleri göstergeler ise evin adresini söyler, telefon numarasını söyler, gerekli zamanlarda uzlaşmacı davranır, sanat eserleri ile ilgili duygularını açıklar, sanat eserlerinde gördüklerini ve işittiklerini söyler şeklindedir. Çocukların sosyal ve duygusal becerilerini geliştirmek için farklı ülkelerde uygulanan programlarda (Denham \& Burton 2003; Barnett et al. 2008; WebsterStratton et al. 2008) daha çok kendisinin ve başkalarının davranışlarının, duygularının ve düşün- 
celerinin farkında olma, sorumluluk alma, davranış yönetimi gibi beceriler üzerinde durulduğu görülmüştür. Bu sonuç araştırmada öğretmenlerin bazı kazanımlara neden daha çok yer verdikleri sonucunu desteklemektedir.

Öğretmenlerin etkinlik planlarında sosyal ve duygusal gelişime sıklıkla Türkçe ve sanat etkinliklerinde yer verdikleri, en az ise alan gezisi ve matematik etkinliklerinde yer verdikleri tespit edilmiştir. Öğretmenlerin planlarında sosyal ve duygusal gelişime en çok bütünleştirilmiş etkinlik biçiminde yer verdikleri görülmüştür. Bu noktada MEB Okul Öncesi Eğitimi Programı Kazanım ve Göstergelere Aylık Eğitim Planlarında Yer Verme Durumu Çizelgesinden yeterince yararlanılmadığı sonucu da ortaya çıkmaktadır. Aksi halde okul öncesi öğretmenlerinin hazırladığı etkinlik planlarında kazanım ve göstergelerin dengeli dağılması beklenmektedir. Tespit edilen bu gibi durumların önüne geçebilmek için okul öncesi öğretmen adaylarına üniversite eğitimi esnasında çocuğu tanıma ve değerlendirmenin yanı sıra uygulamaya dönük eğitim verilmesi de önerilmektedir (Güder et al. 2018).

Okul öncesi öğretmenlerinin etkinlik türü bakımından sosyal ve duygusal gelişime ait kazanımlara en az yer verdikleri etkinliklerin alan gezisi etkinliği ve matematik etkinliği olması çalışmada dikkat çeken bir diğer husustur. Bu durumun çalışmanın yapıldığı bölgedeki iklim şartlarından, coğrafi yapıdan ve sosyo-ekonomik koşullardan kaynaklandığı düşünülmektedir. Ağrı ili merkez ilçe de okul öncesi eğitim dönemindeki çocukların alan gezisi yapabileceği müze vs. olmaması bilinmesine karşın yine de bu dönem çocuklarının dört duvar arasına sıkıştırılması, alan gezilerinden mahrum edilmesi kabul edilemez bir durumdur. Çükü bir ekmek firınına, bir huzur evine, bir hayvan çiftliğine, bir resim atölyesine ve ya bir buğday tarlasına özellikle aile katılımının da sağlanarak düzenlenecek alan gezisi etkinlikleri ile çocuklar gözlem ve inceleme şansı elde ederken hem çok eğlenecek, hem de sosyal ve duygusal gelişim alanında ciddi yol kat edecektir (Kızıltaş \& Sak 2018). Burada büyük oranda sorumluluğu başta okul öncesi öğretmenleri ve yöneticilerin yanı sıra il milli eğitim müdürlüğü ve diğer paydaş kurumların üstlenmesi beklenmektedir. Matematik etkinliklerinde sosyal ve duygusal gelişime yönelik kazanımlara yer verilememesinin nedeni olarak ise öğretmenlerin matematik etkinliklerinde belli kalıpları takip ettikleri (Bağcı \& İvrendi 2016) ve hizmet içi eğitim ihtiyaçları olduğu düşünülmektedir. Öğretmenlerin sosyal ve duygusal gelişime yönelik kazanımlara en çok Türkçe etkinliklerinde yer vermesinin nedeni olarak bölgede anadili Kürtçe olan çocuk sayısının yoğun olması nedeni ile okul öncesi eğitiminin amaçları içerisinde yer alan "çocukların Türkçeyi doğru ve güzel konuşmalarını sağlamak" (MEB 2013), amacına ulaşma isteği olduğu düşünülmektedir.

$\mathrm{Bu}$ araştırmada okul öncesi öğretmenlerinin hazırladıkları etkinlik planlarında sosyal ve duygusal gelişim alanına yer verme düzeyi araştırılmıştır. Yapılacak farklı çalışmalarla; öğretmenlerin kazanım ve göstergelere yer verme düzeylerinin nedenleri mülakatlar aracılığı ile araştırılabilir. Ayrıca öğretmenlerin etkinlik planlarında bilişsel, psiko-motor, dil ve öz bakım becerilerine yer verme düzeylerinin incelendiği ve nedenlerinin irdelendiği detaylı çalışmalarında alana katkı sağlayacağı düşünülmektedir.

\section{Yazarın Notu}

Bu çalışma 21-24 Nisan 2016 tarihinde Antalya'da düzenlenen 25. Ulusal Eğitim Bilimleri Kongresinde sözlü bildiri olarak sunulmuştur.

\section{Editörün Notu}

Makale 2017 yılı içerisinde tarafımıza ulaşmış, hakem süreci henüz tamamlandığı ve yayın hakk1 olduğu için bu sayımızda yayınlanmıştır. 


\section{KAYNAKÇA}

Ayyıldız T. (2011). 6 Yaş (60-72 Ay) Çocuklarda Sosyal Beceri Geliş̧tirerek Şiddeti Önleme Programının Etkisi. Yayımlanmamış Doktora Tezi. Marmara Üniversitesi, İstanbul 2011.

Bağc1 B. \& İvrendi A. (2016). "Türkiye'de Okul Öncesi Dönem Matematik Becerileri ve Eğitimi Araştırmaları: Sentez Çalışması”. Necatibey Eğitim Fakültesi Elektronik Fen ve Matematik Eğitimi Dergisi 23/3 (2016).

Ball C. (1994). Start Right: The Importance of Early Learning. London 1994.

Barnett W. S., Jung K., Yarosz D. J., Thomas J., Hornbeck A., Stechuk R. \& Burns S. (2008). "Educational Effects of the Tools of the Mind Curriculum: A Randomized Trial". Early Childhood Research Quarterly 23/3 (2008) 299-313.

Bikos K. \& Gregoriadis A. (2012). "Moral Judgments of Sociometrically Neglected Children Concerning Their Bullying Experiences in the First Grade". International Journal of Humanities and Social Science 2/3 (2012) 23-33.

Blair C. (2002). "School Readiness: Integrating Cognition and Emotion in a Neurobiological Conceptualization of Children's Functioning at School Entry". American Psychologist 57 (2002) 111-127.

Boyd J., Barnett W. S., Bodrova E., Leong D. J., Gomby D., Robin K. B. \& Hustedt J. T. (2005). Promoting Children's Social and Emotional Development Through Preschool. New Brunswick 2005.

Ceylan Ş. (2009). Vineland Sosyal-Duygusal Erken Çocukluk Ölçeğinin Geçerlik-Güvenirlik Çalışması Ve Okul Öncesi Eğitim Kurumuna Devam Eden Beş Yaş Çocuklarının Sosyal-Duygusal Davranışlarına Yaratıcı Drama Eğitiminin Etkisinin İncelenmesi. Yayımlanmamış Doktora Tezi. Gazi Üniversitesi, Ankara 2009.

Cohen L. \& Manion L. (1992). Research Method in Education. London-New York 1992.

Curtis A. (2002). A Curriculum for the Pre-School Child Learning to Learn. Londonans New York 2002.

Denham S. A. \& Burton R. (2003). Social and Emotional Prevention and Intervention Programming for Preschoolers. New York 2003.

Dereli E. (2008). Çocuklar İ̧̧in Sosyal Beceri Eğitim Programının 6 Yaş Çocukların Sosyal Problem Çözme Becerilerine Etkisi. Yayımlanmamış Doktora Tezi. Selçuk Üniversitesi, Konya 2008.

Drummond M. J. (1993). Assessing Children's Learning. London 1993.

Duncan G. J., Dowsett C. J., Claessens A., Magnuson K., Huston A. C., Klebanov P. \& Japel C. (2007). "School Readiness and Later Achievement". Developmental Psychology 43 (2007) 1428-1446. Doi: 10.1037/0012-1649.43.6.1428.

Early Childhood Education Forum (1997). Quality in Diversity in Early Learning. (Draft).

Elkinson L. \& Elkinson N. (2000). "Teaching Parents to Teach Their Children to Be Prosocial". Intervention in School and Clinic 36/1 (2000) 27-37.

Eisenberg N., Smith C. L., Sadovsky A. \& Spinrad T. L. (2004). "Effortful Control: Relations with Emotion Regulation, Adjustment, and Socialization in Childhood". Eds. R. F. Baumeister \& K. D. Vohs, Handbook of Self-Regulation: Research, Theory, and Applications (2004) 259-282. New York.

Eraslan-Çapan B. (2006). Çocukların Kendilik Değerini Geliştirmede Kendilik Değerini Geliştirme Programı ve Sosyal ve Duygusal Eğitim Programının Etkililiği. Yayımlanmamış Doktora Tezi. Hacettepe Üniversitesi, Ankara 2006.

Fergusson D. M., Woodward L.J. \& Horwood L. J. (2000). "Risk Factors and Life Processes Associated with the Onset of Suicidal Behaviour During Adolescence and Early Adulthood". Psychological Medicine 30/1 (2000) 23-39.

Gregoriadis A., Grammatikopoulos V. \& Zachopoulou E. (2013). "Evaluating Preschoolers' Social Skills: The Impact of a Physical Education Program from the Parents' Perspective". International Journal of Humanities and Social Science 3/10 (2013) 40-51.

Güder S. Y., Alabay E. \& Güner E. (2018). "Okul Öncesi Öğretmenlerinin Sınıflarında Karşıllaştıkları Davranış Problemleri ve Kullandıkları Stratejiler”. Ilköğretim Online 17/1 (2018) 414-430.

Gülay H. (2008). 5-6 Yaş Çocuklarına Yönelik Akran İlişkileri Ölçeklerinin Geçerlik Güvenirlik Çalışmaları ve Akran İlişkilerinin Çeşitli Değişkenler Açısından İncelenmesi. Yayımlanmamış Doktora Tezi. 
Marmara Üniversitesi, İstanbul 2008.

Günindi Y. (2010). Anasınıfına Devam Eden Altı Yaş Çocuklarına Uygulanan Sosyal Uyum Beceri Eğitimi Programının Çocukların Sosyal Uyum Beceri Eğitimi Programının Çocukların Sosyal Uyum Becerilerinin Gelişimine Etkisi. Yayımlanmamış Doktora Tezi. Gazi Üniversitesi, Ankara 2010.

Han H.S. (2012). "Professional Development that Works: Shifting Preschool Teachers' Beliefs and Use of Instructional Strategies to Promote Peer Social Competence”. Journal of Early Childhood Teacher Education 33/3 (2012) 251-268.

Hemmeter M. L., Santos R. M. \& Ostrosky M. M. (2008). "Preparing Early Childhood Educators to Address Young Children's Social-Emotional Development and Challenging Behavior: A Survey of High Ereducation Programs in Nine States". Journal of Early Intervention 30/4 (2008) 321-340.

Hollingsworth H. L. \& Winter M. K. (2013). "Teacher Beliefs and Practices Relating to Development in Preschool: Importance Placed on Social-Emotional Behaviours and Skills". Early Child Development and Care 183/12 (2013) 1758-1781. Doi: 10.1080/03004430.2012.759567.

Howse R. B., Lange G., Farran D. C. \& Boyles C. D. (2003). "Motivation and Self-Regulation as Predictors of Achievement in Economically Disadvantaged Young Children”. Journal of Experimental Education 71/2 (2003) 151-174.

Kızıltaş E. \& Sak R. (2018). "Integrating Field-Trip Activities With Other Activities in the Preschool Curriculum: Its Effects on the Preschoolers' Social-Emotional Skills". International Journal of Child Care and Education Policy 12/8 (2018).

Kuru-Turaşlı N. (2012). Okul Öncesi Eğitimin Tanımı, Kapsamı ve Önemi. Ed. G. Haktanır, Okul Öncesi Eğitime Giriş (2012) 1-22. Ankara.

Kuru-Turaşlı N. (2006). 6 Yaş Grubu Çocuklarda Benlik Algısını Desteklemeye Yönelik Sosyal-Duygusal Hazırlık Programı'nın Etkililiğinin İncelenmesi. Yayımlanmamış Doktora Tezi. Marmara Üniversitesi, İstanbul 2006.

Kupersmidt J. B. \& Coie J. D. (1990). "Pre Adolescent Peer Status, Agreesion, and School Adjustment as Predictors of Externalizing Problems in Adolescence”. Child Development 61/5 (1990) 1350-1362.

Ladd G. (1990). "Having Friends, Keeping Friends, Making Friends, and Being Liked by Peers in the Classroom: Predictors of Children's Early School Adjustment". Child Development $61 / 4$ (1990) 1081-1100.

Ladd G. W., Kochenderfer B. J. \& Coleman C. C. (1996). "Friendship Quality as a Predictor of Young Children's Early School Adjustment”. Child Development 67/3 (1996) 1103-1118.

Lillvist A., Sandberg A., Björck-Åkesson E. \& Granlund M. (2009). "The Construct of Social Competence How Preschool Teachers Define Social Competence in Young Children". International Journal of Early Childhood 41/1 (2009) 51-68.

Masten A. S. \& Coatsworth J. D. (1998). "The Development of Competence in Favourable and Unfavourable Environments: Lessons from Research on Successful Children”. American Psychologist 53 (1998) 205-220.

McClelland M. M., Cameron C. E., Wanless S. B. \& Murray A. (2007). "Executive Function, Behavioral Self-Regulation, Andsocial-Emotional Competence: Links to School Readiness". Eds. O. N. Saracho \& B. Spodek, Contemporary Perspectives on Social Learning in Early Childhood Education (2007) 83-107. Charlotte.

McClelland M. M., Morrison F. J. \& Holmes D. L. (2000). "Children at Risk for Early Academic Problems: The Role of Learning-Related Social Skills". Early Childhood Research Quarterly 15/3 (2000) 307-329.

MEB (2013) "Milli Eğitim Bakanlığı Temel Eğitim Genel Müdürlüğü Okul Öncesi Eğitim Programı”. Kaynak: <https://tegm.meb.gov.tr/dosya/okuloncesi/ooproram.pdf>.

OBADER (2013). “Okul Öncesi Eğitim Programı ile Bütünleştirilmiş Aile Destek Eğitim Rehberi”. Kaynak: <https://cocukhizmetleri.aile.gov.tr/duyurular/036-ve-3772-aylik-cocuklara-yonelik-programlar>.

Özbey S. (2009). Anaokulu ve Anasınıfı Davranış Ölçeği’nin (PKBS-2) Geçerlik ve Güvenirlik Çalışması ve Destekleyici Ĕgitim Programının Etkisinin İncelenmesi. Yayımlanmamış Doktora Tezi. Gazi Üniversitesi, Ankara 2009. 
Özdemir-Topaloğlu A. Ö. (2013). Etkinlik Temelli Sosyal Beceri Eğitiminin Çocukların Akran Illişkilerine Etkisi. Yayımlanmamış Doktora Tezi. Selçuk Üniversitesi, Konya 2013.

Pekdoğan S. (2016). "Hikâye Temelli Sosyal Beceri Eğitim Programının 5-6 Yaş Çocukların Sosyal Becerilerinin Gelişimine Etkisi”. Eğitim ve Bilim 41/183 (2016) 305-318.

Pianta R. C., Barnett W. S., Burchinal M. \& Thornburg K. R. (2009). "The Effects of Preschool Education: What We Know, How Public Policy is or is not Aligned With the Evidence Base, and What We Need to Know". Psychological Science in the Public Interest 10/2 (2009) 49-88.

Rimm-Kaufman S. E., Pianta R. C. \& Cox M. J. (2000). "Teachers' Judgments of Problems in the Transition to Kindergarten". Early Childhood Research Quarterly 15/2 (2000) 147-166.

Rivers S. E., Tominey S. L., O’Bryon E. C. \& Brackett M. A. (2013). "Introduction to the Specialissue on Social an Emotional Learning in Early Education". Early Education and Development 24/7 (2013) 953-959. Doi:10.1080/10409289. 2013. 825364.

Rubin K. H., Bukowski W. M. \& Parker J. G. (2006). "Peer Interactions, Relationships, and Groups". Eds. W. Damon, R. M. Lerner \& N. Eisenberg, The Handbook of Child Psychology: Vol. 3. Social, Emotional, and Personality Development $\left(2006^{6}\right)$ 571-645). New York.

Serpell Z. N. \& Mashburn A. J. (2012). "Family-School Connectedness and Children's Early Social Development". Social Development 21/1 (2012) 21-46.

Seven S. (2006). 6 Yaş Çocuklarının Sosyal Beceri Düzeyleri ile Bağlanma Durumları Arasındaki İlişkilerin Incelenmesi. Yayımlanmamış Doktora Tezi. Gazi Üniversitesi, Ankara 2006.

Tremblay R. E., Masse B., Perron D., Leblanc M., Schwartzman A. E. \& Ledingham J. E. (1992). "Early Disruptive Behavior, Poor School Achievement, Delinquent Behavior, and Delinquent Personality: Longitudinal Analyses". Journal of Consulting and Clinical Psychology 60/1 (1992) 64-72.

Yıldırım A. \& Şimşek H. (2006). Sosyal Bilimlerde Sosyal Araştırma Yöntemleri. Ankara 2006.

Yüksel S. (2011). "Fen-Edebiyat Fakültesi Öğretim Üyelerinin Öğretmen Yetiştirme Sistemine İlişkin Düşünceleri (Uludağ Üniversitesi Fen-Edebiyat Fakültesi Örneği)". Kuram ve Uygulamada Eğitim Bilimleri 11/1 (2011) 179-198.

Zigler E. F. \& Bishop-Josef, S. J. (2006). "The Cognitive Child vs. the Whole Child: Lessons from 40 Years of Head Start". Eds. D. G. Singer, R. M. Golinkoff, \& K. Hirsh-Pasek, Play=Learning: How Play Motivates and Enhances Children's Cognitive and Social-Emotional Growth (2006) 15-35. New York.

Webster-Stratton C., Reid J. M. \& Stoolmiller M. (2008). "Preventing Conduct Problems and Improving School Readiness: Evaluation of the Incredible Years Teacher and Child Training Programs in HighRisk Schools". Journal of Child Psychology and Psychiatry 49 (2008) 471-488.

Wang J., Elicker J., McMullen M. \& Mao S. (2008). "Chinese and American Preschool Teachers' Beliefs About Early Childhood Curriculum”. Early Child Development and Care 178/3 (2008) 227-249. 
